\title{
TOXICOLOGICAL AND BIOLOGICAL EFFECT OF THREE CHEMICAL COMPOUNDS ON DIFFERENT HONEY BEE RACES (APIS MELLIFERA L.) (HYMENOPTERA: APIDAE)
}

\author{
RuKhosh, J. R. ${ }^{1}-$ ABdulbast, M. A..$^{2 *}$ TAlal, T. M. ${ }^{3}$ \\ ${ }^{I}$ College of Agriculture Science, University of Sulaimani, Sulaimani, Iraq \\ (e-mail: Rukhosh.rashed@univsul.edu.iq) \\ ${ }^{2}$ Forestry Department, Agriculture College, Salahadden University, Erbil, Iraq \\ ${ }^{3}$ College of Agriculture, University of Duhok, Duhok, Iraq \\ (e-mail: talphys_99@yahoo.com) \\ *Corresponding author \\ e-mail:profabed57@yahoo.com \\ (Received $18^{\text {th }}$ Dec 2018; accepted $20^{\text {th }}$ Feb 2019)
}

\begin{abstract}
This study consisted of the chemical treatment on three races of forager honey bee workers in Sulaimani-Kurdistan region. The races included, Apis mellifera carnica, Apis mellifera ligustica and Apis mellifera Native. The TITAN 48\% herbicide affected Apis mellifera carnica the most by ingestion, leading to $83.67 \%$ mortality after $48 \mathrm{~h}$ at $1.00 \mathrm{ppm}$, which increased to $100 \%$ at $10.00 \mathrm{ppm}$. Apis mellifera Native was most affected by the insecticide Goldti5 through feeding, which led to $50.00 \%$ mortality after $48 \mathrm{~h}$ at $1.0 \mathrm{ppm}$ and rose to $100 \%$ at $10.00 \mathrm{ppm}$. TITAN $48 \%$ herbicide had the most severe effect on Apis mellifera ligustica through feeding, leading to almost $100 \%$ mortality in all concentrations after $48 \mathrm{~h}$. Laboratory test indicated that fat cells showed a series of changes in the cytoplasm when exposed to the recommended dose. The granulated cytoplasm developed a few droplets while the nucleus remained unchanged.
\end{abstract}

Keywords: honey bee, foragers, fat body, insecticides, herbicides

\section{Introduction}

Chemical insecticides are important in crop productivity in intensive farming systems, maintaining about one and a half crop yields (Oerke and Dehne, 2004). Bohnenblust et al. (2016) found that nearly $80 \%$ of all pesticides applied to row crops are herbicides, and these applications pose potentially significant ecotoxicological risks to nontarget plants and associated pollinators. When used, pesticides can cause unintentional damage by killing useful insects, such as pollinators and natural enemies of crop pests, both within the target field (Croft, 1990) and beyond by drifting (De Jong et al., 2008). Most pesticides are used as sprays, but such herbicides and fungicides are usually used directly on the soil before planting crops. Krupke et al. (2012) demonstrated that bees are exposed to these compounds and several other agricultural pesticides in several ways throughout the foraging period. During spring, extremely high levels of clothianidin and thiamethoxam were found in planter exhaust material produced during the planting of treated maize seed. Growing concern about the impact of pesticides on pollinators is reflected in the vast literature on the subject of the last few years (Osborne, 2012). The sublethal impacts of GLY on non-target organisms such as insect pollinators have so far been poorly evaluated. In this study, we used sublethal concentrations of GLY ranging from 2.5 to $10 \mathrm{mg} \mathrm{l}^{-1}$ (Herbert et al., 2014; Thompson et al., 2014). Sol Balbuena et al. (2015) demonstrated that glyphosate (GLY) is a herbicide 
that is widely used in agriculture for weed control. Although reports about the impact of GLY in snails, crustaceans and amphibians exist, few studies have investigated its sublethal effects in non-target organisms such as the honey bee Apis mellifera, the main pollen vector in commercial crops. Particular importance is the collapse of bee colonies (Apis mellifera) called Colony collapse disorder (CCD). Attempts to interpret the UNCCD have focused on biological diseases, including viruses (Cox-foster et al., 2007), nosema infection (Cameron et al., 2011), parasites such as mites (Thompson et al., 2003; Underwood and Engelsdrop, 2007) and beetles (Buczek (2009), including not only insecticides and corticosteroids but also fungicides and herbicides (Maini et al., 2010; Johnson et al., 2010).

Apart from pesticides used in agricultural production, honey bees are also exposed to the acaricides used to control varroa and other parasites. In this case, the bees interact with high residue levels on the waxy cells of the comb, which mainly affect the developing larvae, the adult honey bees and the queen (Martel et al., 2007; Zhu et al., 2014). Fat bodies are normally distributed throughout the body cavity of insects, especially in the abdomen, and appear as an irregular mass of a soft and usually white tissue composed of large loosely united cells. These cell masses are known collectively as fat body, because the cytoplasm of the cells contains small droplets of oily fat (Snodgrass and Erickson, 2003). The fat bodies can be irregularly distributed in the perivascular space of the abdomen and thorax, surrounding the organs (visceral fat body) or in the abdomen dorsal and ventral sinus, closed to the tegument (parietal fat body), in the head and even in the body appendixes (Chapman, 1978; Zanini and Caetano, 2003). Ayoub (2011) found that the average dimension of fat body cells in newly emerged workers is between $86.71-86.76 \mu \mathrm{m}$ and in 10-days old workers the average dimension of fat body cells is between $89.15-89.95 \mu \mathrm{m}$ while the average dimensions of fat body cells ranges between 67.33 and $69.05 \mu \mathrm{m}$. Fat body is the main storage agent of the metabolic device of insects and is responsible for the synthesis and supply of hemolymphs. Fat body is made up of cells of mesodermal origin, and sometimes contain epidermal cells (Oliveira and Cruz-Landim, 2003). Roma et al. (2010) demonstrated that fat body consists of a mass of cells under the epidermis, and in some insects, fat body also surrounds the digestive system and reproductive system.

The aim of this research was to shed light on the pesticides that were most commonly used in the study region to determine the sensitivity of the studied honey bee races (strains) to the lowest concentration of these pesticides, then determine the proportion of mortality and the histological properties of these strains under natural condition.

\section{Materials and methods}

Collection of forager honey bees was done at an apiary, and included three races of Honey bees: Apis mellifera carnica, Apis mellifera ligustica, Apis mellifera Native in April 2017. Ten foragers of each race were placed into an experimental box ( $30 \mathrm{X} 30 \mathrm{X}$ $30 \mathrm{~cm}$ ) and fed with the sugar syrup that was treated with two types of insecticide and one type herbicide that are common used on the fields near the honey bee hives, with three replications. Four concentrations ( $1 \mathrm{ppm}, 2.5 \mathrm{ppm}, 5.00 \mathrm{ppm}, 10.00 \mathrm{ppm})$ for the two types of insecticide were prepared as follows: $0.1 \mathrm{gm}$ of insecticide was added to a volume of sucrose solution $(10 \% \mathrm{~W} / \mathrm{V})$ which was then filled up to $1000 \mathrm{ml}$ with the same solution to obtain $10 \mathrm{ppm}$ of insecticides. Following this, the other three concentrations $(5.00 \mathrm{ppm}, 2.500 \mathrm{ppm}$ and $1.00 \mathrm{ppm})$ of insecticides were directly 
prepared from stock solution with sucrose solution (10\% W/V) dilution. Additionally, the four concentrations of the herbicide were prepared as follows: the same procedure was used as in the preparation of the insecticide solutions. The mortality of the foragers were measured after 1, 2, 4, 6 and 24 hours, and the mortality percentage ratio has been re-evaluated using Abbott's (1925) formula.

\section{Insecticides}

In this experiment the forager honey bees were exposed to three different insecticides:

\section{Goldti 5EC}

The active ingredient is Lambda-cyhalothrin, a quick-acting pyrethroid insecticide effective after contact or ingestion (Dalaly et al., 2012). Lambda-cyhalothrin is a synthetic pyrethroid based structurally on natural pyrithrins. Lambda-cyhalothrin affects both the peripheral and central nervous system of the insect. It initially stimulates nerve cells to produce repetitive discharges and eventually cause paralysis. These sympthoms are caused by their effect on the sodium channel, a tiny hole through which sodium ions are permitted to enter the axon to cause excitation (Ware and Whitacre, 2004).

Chemical structure of Lambdacyhalothrin/chemical name: $\left.[1 \alpha(\mathrm{S}), 3 \alpha(\mathrm{Z})]_{-(-}{ }^{+}\right)-$ cyano-(3-phenoxyphenyl) methyl-3-(2-chloro-3, 3, 3-trifluoro-1propenyl)-2, 2dimethylcyclopropanecarboxylate.

\section{Delta ride}

The active ingredient is Acetamiprid, a systemic pesticide used to control many sucking insects, which acquired immunity against other pesticides, used on vegetables, fruit trees and other plants. The effect appears after a few minutes of spraying. Used in a concentration of (50) gm /100 litter of water, it was sprayed on and consumed by the forager honey bee workers using a hand sprayer (Dalaly et al., 2012).

Chemical structure of Acetamiprid/chemical name: (E)-N'-[(6-chloro-3pyridyl) methyl]- $\mathrm{N}^{2}$-cyano- $\mathrm{N}^{1}$-methyl acetamidine.

\section{TITAN $48 \%$}

The active ingredient is Paraquat or $\mathrm{N}, \mathrm{N}^{\prime}$-dimethyl-4,4'-bipyridinium dichloride, an organic compound with the chemical formula $\left[\left(\mathrm{C}_{6} \mathrm{H}_{7} \mathrm{~N}\right)_{2}\right] \mathrm{Cl}_{2}$. It is classified as a viologen, a family of redox-active heterocycles of similar structure. Paraquat was manufactured by Chevron (Dalaly and et al., 2012).

Chemical structure/Chemical name: 1, $1^{1}$-dimethyle-4, 4-bipyridinium.

Concentration: Four different concentrations were prepared from each insecticide (Lambdacyhalothrin, Acetamiprid, Paraquat). The concentrations were chosen by preliminary range-finding tests (OECD, 1998b; Maus, et al., 2003; Tornier, et al., 2003). The concentrations used were as follows:

1. $1.00 \mathrm{ppm}, 2.50 \mathrm{ppm}, 5.00 \mathrm{ppm}$, and $10.00 \mathrm{ppm}$ for (Lambdacyhalothrin, Paraquat) the active ingredients. These four concentration of (TITAN 48\%, Goldti 5EC) were prepared as follows: 
a. $0.4 \mathrm{ml}$ of TITAN 48\%/Goldti 5EC was added to a volume of sucrose solution $(50 \% \mathrm{w} / \mathrm{v})$, which was then filled up to $1000 \mathrm{ml}$ by the same solution to obtain 10.0 ppm Lambdacyhalothrin/Paraquat for the ingestion experiment.

b. The three other concentration $(5.00 \mathrm{ppm}, 2.50 \mathrm{ppm}$, and $1.00 \mathrm{ppm}$ of Lambdacyhalothrin and Paraquat) were directly prepared from the previously prepared solution of step (a) or (b), diluted with a sucrose solution $(50 \% \mathrm{w} / \mathrm{v})$ or distilled water for the ingestion and contact experiments, respectively.

2. $1.00 \mathrm{ppm}, 2.50 \mathrm{ppm}, 5.00 \mathrm{ppm}$, and $10.00 \mathrm{ppm}$ for the Acetamiprid active ingredient were prepared as follows:

$0.1 \mathrm{gm}$ of Delta Ride was added to a volume of sucrose solution (10\% W/V) which was then filled up to $1000 \mathrm{ml}$ by the same solution to obtain $10 \mathrm{ppm}$ of Acetamiprid, then the other three concentration of $(5,2.5$ and $1 \mathrm{ppm})$ of acetamiprid were directly prepared from the stock solution by diluting it with sucrose solution $(10 \% \mathrm{~W} / \mathrm{V})$.

\section{Samples collected}

Ten workers of each stage were taken for the measurements such as the dimensions of fat bodies and, using binocular dissection and a digital microscope. The ages of worker were recorded (one day, one week, two weeks and three weeks old).

\section{Dissection}

The workers were fixed on the dissecting tray after the removal of legs and wings, then immersed in physiological solution. These units were transferred to the dissecting microscope and placed upside down on the tray and fixed with pins. Workers were dissected using a sharp scalpel to create two lateral longitudinal cleavages of the abdomen after mounting the specimens on the dissecting tray with fine stainless pins (Cook and Meola, 1983; Mahmoud, 1991, 1992; Shamdin, 2003). The workers were kept in Physiological saline of $0.9 \% \mathrm{NaCl}$ and $0.9 \mathrm{gm}$ per $100 \mathrm{ml}$ distilled water (Pantin, 1964). The fixed workers were dissected under $2 \mathrm{x}$ and $4 \mathrm{x}$ magnification. After cutting the cuticle and removing the muscles, the fat bodies were picked up and placed on a clean slide and were either stained with methylene blue in normal quantities, or prepared with a wet smear. Then photographs and measurements were taken with the eyepiece graticule.

Climatic information data was acquired from Sulaimani General Directorate Meteorology and Seismology.

The results were analyzed statistically using factorial RCBD design with triple replicates and performed using the XLSTA program (2016). Duncan's multiple range Test was used to determine the differences between means at $\mathrm{P}=0.05$

\section{Results and discussion}

\section{The effects of insecticides applied orally to Apis mellifera carnica}

Table 1, among others, showed the relation among insecticides, insecticide concentrations and exposure time (ABC). The lowest mortality rate was 1.00 after $1 \mathrm{~h}$ of treatment with a concentration of $2.50 \mathrm{ppm}$ of TITAN $48 \%$ for A. mellifera carnica. However, the highest mortality rate was 5.333 after $1 \mathrm{~h}$ of treatment with a concentration of $100 \%$ of Goldti5 for A. mellifera carnica. While the lowest mortality rate was 2.667 after $2 \mathrm{~h}$ of treatment with $1.00 \mathrm{ppm}$ of TITAN $48 \%$ and Goldti5 for $A$. 
mellifera carnica, the highest mortality rate was 8.667 after $2 \mathrm{~h}$ of treatment with 5.00 ppm of Goldti5 for adult A. mellifera carnica. The lowest mortality rate was 3.000 after $4 \mathrm{~h}$ of treatment with $1.00 \mathrm{ppm}$ of Delta ride for the adult A. mellifera carnica. However, the highest mortality rate was 8.333 after $4 \mathrm{~h}$ of treatment with a concentration of $10.00 \mathrm{ppm}$ of Delta ride for the adult A. mellifera carnica. Similarly, the lowest mortality rate of 3.333 was established after $6 \mathrm{~h}$ in the $1.00 \mathrm{ppm}$ concentration. In addition, the highest mortality rate of 9.667 was observed in 10.00 ppm of Goldti5 after $6 \mathrm{~h}$ for adult A. mellifera carnica. The lowest mortality rate of 4.667 was established after $24 \mathrm{~h}$ in the $1.00 \mathrm{ppm}$ for Delta ride, while the highest mortality rate of 10.00 was observed in $10.00 \mathrm{ppm}$ of Delta Ride, Goldti5 and 2.50, 5.00 , and $10.00 \mathrm{ppm}$ concentrations of TITAN $48 \%$ after $24 \mathrm{~h}$ for adult A. mellifera carnica. As for the relation between insecticides and insecticide concentrations (AB), the lowest mortality rate was 2.466 at $1.00 \mathrm{ppm}$ for Delta ride, the highest mortality rate was 8.200 at $10.00 \mathrm{ppm}$ for Goldti5 in the case of adult A. mellifera carnica, in comparison with controls. Concerning the relation between insecticides and test periods (AC), the lowest mortality rate was 1.266 after $1 \mathrm{~h}$ for TITAN $48 \%$, and the highest mortality rate was 7.000 after $24 \mathrm{~h}$ for TITAN $48 \%$ and Goldti5 in the case of adult $A$. mellifera carnica. As for the relation between insecticide concentrations and test periods (BC), the lowest mortality rate was 0.000 at a concentration of $1.00 \mathrm{ppm}$ after $1 \mathrm{~h}$, while the highest mortality rate was 10.000 at a concentration of $10.00 \mathrm{ppm}$ after $24 \mathrm{~h}$ of testing, in comparison with controls. The relation between each insecticide (A) showed the lowest mortality rate to be 3.866 for Delta ride, while the highest mortality rate was 5.333 for Goldti5, at the significance level of $\mathrm{P}<0.05$ there was a significant difference among Delta ride, TITAN 48\% and Goldti5. The relation between each insecticide concentration (B) showed the lowest mortality rate to be 3.511 at $1.00 \mathrm{ppm}$ and the highest mortality rate was 7.510 at $10.00 \mathrm{ppm}$ in the case of adult A. mellifera carnica, in comparison with control. As for the relation between each test period (C), the lowest mortality rate was 1.933 after $1 \mathrm{~h}$, and the A. mellifera carnica mortality rate increased with time, up to 6.844 after $24 \mathrm{~h}$.

Table 1. Mean numbers of A. mellifera carnica mortality after being treated with various concentrations of insecticides through feeding

\begin{tabular}{|c|c|c|c|c|c|c|c|c|}
\hline \multirow{2}{*}{$\begin{array}{c}\text { Insecticide } \\
\mathbf{A}\end{array}$} & \multirow{2}{*}{$\begin{array}{c}\text { Concentration } \\
\text { B }\end{array}$} & \multirow[b]{2}{*}{$1 \mathrm{~h}$} & \multirow[b]{2}{*}{$2 \mathrm{~h}$} & \multirow[b]{2}{*}{$4 \mathrm{~h}$} & \multirow[b]{2}{*}{$6 \mathrm{~h}$} & \multirow[b]{2}{*}{$24 \mathrm{~h}$} & \multirow[b]{2}{*}{$\mathbf{A B}$} & \multirow[b]{2}{*}{$\mathbf{A}$} \\
\hline & & & & & & & & \\
\hline \multirow{5}{*}{ Delta Ride } & 0.00 & $0.000 \mathrm{~s}$ & $0.000 \mathrm{~s}$ & $0.000 \mathrm{~s}$ & $0.000 \mathrm{~s}$ & $0.000 \mathrm{~s}$ & 0.000 & \multirow{5}{*}{$3.866 \mathrm{c}$} \\
\hline & $1.00 \mathrm{ppm}$ & $0.000 \mathrm{~s}$ & $1.333 \mathrm{r}$ & 3.000 op & $3.333 \mathrm{o}$ & $4.667 \mathrm{~lm}$ & 2.466 & \\
\hline & $2.50 \mathrm{ppm}$ & $2.333 \mathrm{pq}$ & $3.000 \mathrm{op}$ & $5.000 \mathrm{klm}$ & $4.667 \mathrm{~lm}$ & $5.667 \mathrm{ijkl}$ & 4.133 & \\
\hline & $5.00 \mathrm{ppm}$ & $3.333 \mathrm{o}$ & $4.667 \mathrm{~lm}$ & 6.333 hij & $5.667 \mathrm{ijkl}$ & $8.667 \mathrm{~cd}$ & 5.733 & \\
\hline & $10.00 \mathrm{ppm}$ & $4.667 \mathrm{~lm}$ & $5.667 \mathrm{ijkl}$ & 7.333 efg & 7.333 efg & $10.000 \mathrm{a}$ & 7.000 & \\
\hline \multirow{5}{*}{ TITAN $48 \%$} & 0.00 & $0.000 \mathrm{~s}$ & $0.000 \mathrm{~s}$ & $0.000 \mathrm{~s}$ & $0.000 \mathrm{~s}$ & $0.000 \mathrm{~s}$ & 0.000 & \multirow{5}{*}{$4.813 \mathrm{~b}$} \\
\hline & $1.00 \mathrm{ppm}$ & $0.000 \mathrm{~s}$ & $2.667 \mathrm{op}$ & $5.000 \mathrm{klm}$ & $6.000 \mathrm{ijk}$ & $8.667 \mathrm{~cd}$ & 4.466 & \\
\hline & $2.50 \mathrm{ppm}$ & $1.000 \mathrm{r}$ & 3.667 no & $6.000 \mathrm{ijk}$ & $7.333 \mathrm{efg}$ & $10.000 \mathrm{a}$ & 5.600 & \\
\hline & $5.00 \mathrm{ppm}$ & $1.667 \mathrm{qr}$ & $5.000 \mathrm{klm}$ & 7.667 ef & $9.000 \mathrm{abc}$ & $10.000 \mathrm{a}$ & 6.666 & \\
\hline & $10.00 \mathrm{ppm}$ & 3.667 no & $5.667 \mathrm{ijkl}$ & $8.000 \mathrm{de}$ & $9.333 \mathrm{abc}$ & $10.000 \mathrm{a}$ & 7.333 & \\
\hline
\end{tabular}




\begin{tabular}{|c|c|c|c|c|c|c|c|c|}
\hline \multirow{5}{*}{ Goldti 5Ec } & 0.00 & $0.000 \mathrm{~s}$ & $0.000 \mathrm{~s}$ & $0.000 \mathrm{~s}$ & $0.000 \mathrm{~s}$ & $0.000 \mathrm{~s}$ & 0.000 & \multirow{5}{*}{$5.013 \mathrm{a}$} \\
\hline & $1.00 \mathrm{ppm}$ & $0.000 \mathrm{~s}$ & $2.667 \mathrm{op}$ & 3.667 no & $5.000 \mathrm{klm}$ & $6.667 \mathrm{ghi}$ & 3.600 & \\
\hline & $2.50 \mathrm{ppm}$ & $2.667 \mathrm{op}$ & $5.667 \mathrm{ijkl}$ & $5.333 \mathrm{jklm}$ & 6.333 hij & 8.333 de & 5.666 & \\
\hline & $5.00 \mathrm{ppm}$ & $4.333 \mathrm{mn}$ & $8.667 \mathrm{~cd}$ & $7.000 \mathrm{fgh}$ & $8.000 \mathrm{de}$ & $10.000 \mathrm{a}$ & 7.600 & \\
\hline & $10.00 \mathrm{ppm}$ & $5.333 \mathrm{jklm}$ & 7.667 ef & $8.333 \mathrm{de}$ & $9.667 \mathrm{ab}$ & $10.000 \mathrm{a}$ & 8.200 & \\
\hline \multicolumn{2}{|c|}{$\mathrm{C}$} & 1.933 & 3.755 & 4.844 & 5.444 & 6.844 & 3 & \\
\hline \multirow{3}{*}{$\mathrm{AC}$} & Delta Ride & 2.066 & 2.933 & 4.333 & 4.200 & 5.800 & \multirow{3}{*}{ B } & \\
\hline & TITAN $48 \%$ & 1.266 & 3.400 & 5.333 & 6.333 & 7.733 & & \\
\hline & Goldti 5 & 2.466 & 4.933 & 4.866 & 5.800 & 7.000 & & \\
\hline \multirow{5}{*}{$\mathrm{BC}$} & 0.00 & 0.000 & 0.000 & 0.000 & 0.000 & 0.000 & 0 & \\
\hline & $1.00 \mathrm{ppm}$ & 0.000 & 2.222 & 3.889 & 4.777 & 6.667 & 3.511 & \\
\hline & $2.50 \mathrm{ppm}$ & 2.000 & 4.111 & 5.444 & 6.111 & 8.000 & 5.1332 & \\
\hline & $5.00 \mathrm{ppm}$ & 3.111 & 6.111 & 7.000 & 7.555 & 9.555 & 6.6664 & \\
\hline & $10.00 \mathrm{ppm}$ & 4.555 & 6.333 & 7.888 & 8.777 & 10.000 & 7.5106 & \\
\hline
\end{tabular}

Also Figure 1 pointed out the toxicity regression related to the A. mellifera carnica mortality

\section{Effect of insecticides applied orally to Apis mellifera Native}

Table 2 showed, that concerning the relation among insecticides, insecticides concentration and exposure time (ABC) the lowest mortality rate was 0.00 after $1 \mathrm{~h}$ of treatment with $1.00 \mathrm{ppm}$ of TITAN $48 \%$ for A. mellifera Native. However, the highest mortality rate was 6.333 after $1 \mathrm{~h}$ of treatment with $10.00 \mathrm{ppm}$ of Delta ride and Goldti5 insecticides on $A$. mellifera Native. The lowest mortality rate was 1.333 after $2 \mathrm{~h}$ of treatment with $1.00 \mathrm{ppm}$ of Delta ride and TITAN $48 \%$ for the forager honey bee of $A$. mellifera Native, while the highest mortality rate was 7.333 after a $2 \mathrm{~h}$ treatment of $10.00 \mathrm{ppm}$ of TITAN $48 \%$. The lowest mortality rate was 2.333 after $4 \mathrm{~h}$ of treatment with $1.00 \mathrm{ppm}$ of Delta ride and TITAN $48 \%$ insecticide for A. mellifera Native foragers. However, the highest mortality rate was 8.333 after $4 \mathrm{~h}$ of treatment with $10.00 \mathrm{ppm}$ of Delta ride insecticide for the forager of $A$. mellifera Native. The lowest mortality rate was 3.333 after $6 \mathrm{~h}$ of treatment with $1.00 \mathrm{ppm}$ of Delta ride and TITAN $48 \%$ for $A$. mellifera Native foragers. The highest mortality rate of 9.333 was found after $6 \mathrm{~h}$ of $10.00 \mathrm{ppm}$ TITAN $48 \%$ insecticide treatment. The minimum mortality rate was 4.333 after $24 \mathrm{~h}$ at $1.00 \mathrm{ppm}$ of Delta ride and TITAN $48 \%$ for A. mellifera Native foragers. However, the highest mortality rate was 10.000 after $24 \mathrm{~h}$ of treatment with $10.00 \mathrm{ppm}$ of Delta ride, TITAN $48 \%$ and Goldti5 for foragers of A. mellifera Native. The relation among insecticides and insecticides concentration (AB) showed the lowest mortality rate to be 2.266 at a concentration of $1.00 \mathrm{ppm}$ of TITAN $48 \%$, and the highest mortality rate to be 7.933 at a concentration of $10.00 \mathrm{ppm}$ of Delta ride for $A$. mellifera Native foragers, in comparison with controls. The relation between insecticides and tested periods (AC) showed the lowest mortality rate to be 1.6666 after $1 \mathrm{~h}$ of TITAN $48 \%$ insecticide treatment, while the highest mortality rate was 6.066 after $24 \mathrm{~h}$ of Delta ride and Goldti5 treatments for the foragers of A. mellifera Native. As for the relation between insecticide concentrations and test periods (BC), the lowest mortality rate was 0.444 at $1.00 \mathrm{ppm}$ after $1 \mathrm{~h}$, while the highest mortality rate was 


$$
-5049 \text { - }
$$

10.000 at $10.00 \mathrm{ppm}$ after $24 \mathrm{~h}$ of testing, in comparison with controls. The relation between each insecticides (A) showed the lowest mortality rate to be 3.799 for TITAN $48 \%$, while the highest mortality rate were 4.506 for Delta ride, and at the significance level of $\mathrm{P}<0.05$ there was significant difference between Delta ride, TITAN $48 \%$ and Goldti5. The relation between each insecticide concentration (B) showed the lowest mortality rate to be 2.532 at $1.00 \mathrm{ppm}$ and the highest mortality rate to be 7.799 at 10.00 $\mathrm{ppm}$, for the foragers of $A$. mellifera Native, in comparison with control. The relation between each tested period (C), showed the lowest mortality rate to be 2.466 after $1 \mathrm{~h}$, and that the A. mellifera Native mortality rate increased with time, up to 5.955 after $24 \mathrm{~h}$.

Table 2. Mean of numbers of A. mellifera hybrid mortality after being treated with different concentration of insecticides through feeding

\begin{tabular}{|c|c|c|c|c|c|c|c|c|}
\hline \multirow{2}{*}{$\begin{array}{c}\text { Insecticide } \\
\text { A }\end{array}$} & \multirow{2}{*}{$\begin{array}{c}\text { Concentration } \\
\text { B }\end{array}$} & \multirow[b]{2}{*}{$1 \mathrm{~h}$} & \multirow[b]{2}{*}{$2 \mathrm{~h}$} & \multirow[b]{2}{*}{$4 h$} & \multirow[b]{2}{*}{$6 \mathrm{~h}$} & \multirow[b]{2}{*}{$24 \mathrm{~h}$} & \multirow[b]{2}{*}{$\mathbf{A B}$} & \multirow[b]{2}{*}{$\mathbf{A}$} \\
\hline & & & & & & & & \\
\hline \multirow{5}{*}{ Delta Ride } & 0.00 & $0.000 \mathrm{x}$ & $0.000 \mathrm{x}$ & $0.000 \mathrm{x}$ & $0.000 \mathrm{x}$ & $0.000 \mathrm{x}$ & 0.000 & \multirow{5}{*}{4.506} \\
\hline & $1.00 \mathrm{ppm}$ & $0.333 \mathrm{wx}$ & $1.333 \mathrm{uvw}$ & $2.333 \mathrm{stu}$ & 3.333 pqrs & 4.333 mnop & 2.333 & \\
\hline & $2.50 \mathrm{ppm}$ & $3.000 \mathrm{qrst}$ & 4.333 mnop & $5.333 \mathrm{jklm}$ & 6.333 ghij & $7.333 \mathrm{defg}$ & 5.266 & \\
\hline & $5.00 \mathrm{ppm}$ & $4.667 \mathrm{lmno}$ & $5.667 \mathrm{ijkl}$ & 6.667 fghi & $7.667 \mathrm{cdef}$ & $8.667 \mathrm{bc}$ & 6.667 & \\
\hline & $10.00 \mathrm{ppm}$ & 6.333 ghij & $7.333 \mathrm{defg}$ & $8.333 \mathrm{bcd}$ & $9.333 \mathrm{ab}$ & $10.000 \mathrm{a}$ & 8.266 & \\
\hline \multirow{5}{*}{ TITAN $48 \%$} & 0.00 & $0.000 \mathrm{x}$ & $0.000 x$ & $0.000 \mathrm{x}$ & $0.000 \mathrm{x}$ & $0.000 \mathrm{x}$ & 0.000 & \multirow{5}{*}{3.799} \\
\hline & $1.00 \mathrm{ppm}$ & $0.000 \mathrm{x}$ & $1.333 \mathrm{uvw}$ & $2.333 \mathrm{stu}$ & 3.333 pqrs & 4.333 mnop & 2.266 & \\
\hline & $2.50 \mathrm{ppm}$ & $1.333 \mathrm{uvw}$ & $2.333 \mathrm{stu}$ & 4.000 nopq & $5.000 \mathrm{klmn}$ & 6.000 hijk & 3.733 & \\
\hline & $5.00 \mathrm{ppm}$ & $2.667 \mathrm{rst}$ & 4.333 mnop & 6.333 ghij & $7.333 \mathrm{defg}$ & $8.333 \mathrm{bcd}$ & 5.799 & \\
\hline & $10.00 \mathrm{ppm}$ & 4.333 mnop & 6.000 hijk & $7.333 \mathrm{defg}$ & $8.333 \mathrm{bcd}$ & $10.000 \mathrm{a}$ & 7.199 & \\
\hline \multirow{5}{*}{ Goldti 5Ec } & 0.00 & $0.000 \mathrm{x}$ & $0.000 \mathrm{x}$ & $0.000 \mathrm{x}$ & $0.000 \mathrm{x}$ & $0.000 \mathrm{x}$ & 0.000 & \multirow{5}{*}{4.453} \\
\hline & $1.00 \mathrm{ppm}$ & $1.000 \mathrm{vwx}$ & 2.000 tuv & 3.000 qrst & 4.000 nopq & $5.000 \mathrm{klmn}$ & 3.000 & \\
\hline & $2.50 \mathrm{ppm}$ & $2.667 \mathrm{rst}$ & $3.667 \mathrm{opqr}$ & $4.667 \mathrm{lmno}$ & $5.667 \mathrm{ijkl}$ & 6.667 fghi & 4.667 & \\
\hline & $5.00 \mathrm{ppm}$ & $4.667 \mathrm{lmno}$ & $5.667 \mathrm{ijkl}$ & 6.667 fghi & 7.667 cdef & $8.667 \mathrm{bc}$ & 6.667 & \\
\hline & $10.00 \mathrm{ppm}$ & 6.000 hijk & 7.000 efgh & $8.000 \mathrm{cde}$ & $8.667 \mathrm{bc}$ & $10.000 \mathrm{a}$ & 7.933 & \\
\hline \multicolumn{2}{|r|}{$\mathrm{C}$} & 2.466 & 3.399 & 4.333 & 5.111 & 5.955 & & \\
\hline \multirow{3}{*}{$\mathrm{AC}$} & Delta Ride & 2.866 & 3.733 & 4.533 & 5.333 & 6.066 & \multirow{3}{*}{ B } & \\
\hline & TITAN $48 \%$ & 1.6666 & 2.7998 & 3.9998 & 4.799 & 5.733 & & \\
\hline & Goldti 5 & 2.8668 & 3.6668 & 4.4668 & 5.200 & 6.066 & & \\
\hline \multirow{5}{*}{$\mathrm{BC}$} & 0.00 & 0.000 & 0.000 & 0.000 & 0.000 & 0.000 & 0 & \\
\hline & $1.00 \mathrm{ppm}$ & 0.444 & 1.555 & 2.555 & 3.555 & 4.555 & 2.532 & \\
\hline & $2.50 \mathrm{ppm}$ & 2.333 & 3.444 & 4.666 & 5.666 & 6.666 & 4.555 & \\
\hline & $5.00 \mathrm{ppm}$ & 4.000 & 5.222 & 6.555 & 7.555 & 8.555 & 6.377 & \\
\hline & $10.00 \mathrm{ppm}$ & 5.555 & 6.777 & 7.888 & 8.777 & 10.000 & 7.799 & \\
\hline
\end{tabular}

Figure 2 pointed out the toxicity regression and the mortality of A. mellifera Native 


\section{The effects of insecticides applied orally to A. mellifera ligustica}

In Table 3 we can see the relation among insecticides, insecticides concentration and exposure time $(\mathrm{ABC})$ among others. The minimum mortality rate was shown to be 0.000 after $1 \mathrm{~h}$ of treatment with $1.00 \mathrm{ppm}$ of Delta ride and TITAN $48 \%$ for $A$. mellifera ligustica. However, the highest mortality rate was 8.000 after $1 \mathrm{~h}$ of treatment with $10.00 \mathrm{ppm}$ of Goldti5 insecticides for adult A. mellifera ligustica. The lowest mortality rate was 0.333 after $2 \mathrm{~h}$ of treatment with the $1.00 \mathrm{ppm}$ of Delta ride for the foragers of $A$. mellifera ligustica, while the highest mortality rate was 9.333 after a $2 \mathrm{~h}$ treatment with $10.00 \mathrm{ppm}$ of Goldti5 insecticide. The lowest mortality rate was 1.667 after $4 \mathrm{~h}$ of treatment with $1.00 \mathrm{ppm}$ of Delta ride for A. mellifera ligustica foragers. However, the highest mortality rate was 9.667 after $4 \mathrm{~h}$ of treatment with $10.00 \mathrm{ppm}$ of Goldti5 insecticide for the foragers of A. mellifera ligustica. The lowest mortality rate was 3.667 after $6 \mathrm{~h}$ of treatment with $1.00 \mathrm{ppm}$ concentration Delta ride for A. mellifera ligustica foragers. The highest mortality rate of 10.000 after $6 \mathrm{~h}$ was found in the 10.00 ppm Goldti5 treatment. The lowest mortality rate was 5.333 after $24 \mathrm{~h}$ at $1.00 \mathrm{ppm}$ of Delta ride insecticide, as determined for the foragers of A. mellifera ligustica. However, the highest mortality rate was 10.000 after $24 \mathrm{~h}$ of treatment with $10.00 \mathrm{ppm}$ of Delta ride and Goldti5, and also with 1.000, 2.500, 5.000, and $10.00 \mathrm{ppm}$ of TITAN 48\%, in addition to $5.000 \mathrm{ppm}$ of Goldti5 for A. mellifera ligustica foragers. The relation between insecticides and insecticides concentration (AB) showed the lowest mortality rate to be 2.200 at $1.00 \mathrm{ppm}$ of Delta ride insecticide, while the highest mortality rate of 9.400 was found under $10.00 \mathrm{ppm}$ of Goldti5 for A. mellifera ligustca foragers, in comparison with controls. The relation between insecticides and testing time (AC) showed the lowest mortality rate to be 0.466 after $1 \mathrm{~h}$ of TITAN $48 \%$ insecticide, and the highest mortality rate to be 5.613 after $24 \mathrm{~h}$ of Goldti5 for the foragers of $A$. mellifera ligustica. As for the relation between insecticide concentrations and test periods (BC), the lowest mortality rate was 0.222 at $1.00 \mathrm{ppm}$ after $1 \mathrm{~h}$, while the highest mortality rate was 7.777 at $10.00 \mathrm{ppm}$ after $24 \mathrm{~h}$ of testing, in comparison with controls. As for the relation between each insecticide (A) the lowest mortality rate appeared to be 3.706 for Delta ride, while the highest mortality rate was 5.613 for Goldti5, and at the significance level of $\mathrm{P}<0.05$ there was a significant difference between Delta ride, TITAN 48\% and Goldti5. The relation between each insecticide concentration (B) showed the lowest mortality rate to be 3.177 at $1.00 \mathrm{ppm}$ and the highest mortality rate to be 7.777 at $10.00 \mathrm{ppm}$, for A. mellifera ligustica foragers, in comparison with controls. As for the relation between testing times $(\mathrm{C})$, the lowest mortality rate was 1.755 after $1 \mathrm{~h}$, and the adult $A$. mellifera ligustica mortality rate increased with time, up to 7.377 after $24 \mathrm{~h}$. The increase in exposure time and concentration of pesticide caused increase in the mortality of honeybees. The exposure of $A$. mellifera Native to Delta Ride at a concentration of $2.5 \mathrm{ml} / \mathrm{a}$ gallon of water for $24 \mathrm{~h}$ after feeding caused a $23.00 \%$ mortality.

Figures 1, 2 and 3 illustrate the LC50 values, and the effect comparison of TITAN $40 \%$, Delta ride and Goldti5 on A. mellifera Native. TITAN $40 \%$ had an LC50 value of $1.70 \mathrm{ml} / \mathrm{gallon}$ after $24 \mathrm{~h}$ of exposure after feeding. While Delta ride and Goldti5 had values of 1.45 and 1.37 respectively. In Figures 4, 5 and 6 the result showed that, based on LC50 values, a Goldti5 insecticidal deposit was 1.75 times more effective than that of Delta ride after $24 \mathrm{~h}$ of exposure for A. mellifera carnica, and that Delta Ride insecticidal deposits were 1.63 times more effective than those of TITAN 48\%. Figures 7, 8, 9 show these effects on A. mellifera ligustica. Delta Ride insecticidal deposits were 


$$
-5051 \text { - }
$$

1.17 times more effective than those of TITAN $48 \%$ after $24 \mathrm{~h}$ of exposure, while TITAN 48\% insecticidal deposits were 0.50 times more effective than those of Goldti5.

Table 3. Mean numbers of A. mellifera ligustica mortality subsequently to being treated with different concentration of insecticides orally

\begin{tabular}{|c|c|c|c|c|c|c|c|c|}
\hline \multirow{2}{*}{$\begin{array}{c}\text { Insecticide } \\
\text { A }\end{array}$} & \multirow{2}{*}{$\begin{array}{c}\text { Concentration } \\
\text { B }\end{array}$} & \multicolumn{7}{|c|}{ I } \\
\hline & & $1 \mathrm{~h}$ & $2 \mathrm{~h}$ & $4 \mathrm{~h}$ & $6 \mathrm{~h}$ & $24 \mathrm{~h}$ & AB & A \\
\hline \multirow{5}{*}{ Delta Ride } & 0.00 & $0.000 \mathrm{u}$ & $0.000 \mathrm{u}$ & $0.000 \mathrm{u}$ & $0.000 \mathrm{u}$ & $0.000 \mathrm{u}$ & 0.000 & \multirow{5}{*}{3.706} \\
\hline & $1.00 \mathrm{ppm}$ & $0.000 \mathrm{u}$ & $0.333 \mathrm{tu}$ & 1.667 pqrstu & 3.667 klmno & 5.333 hijk & 2.200 & \\
\hline & $2.50 \mathrm{ppm}$ & $0.333 \mathrm{tu}$ & $2.667 \mathrm{mnopq}$ & $4.333 \mathrm{jklm}$ & 5.667 ghij & 7.333 cdefg & 4.066 & \\
\hline & $5.00 \mathrm{ppm}$ & $1.000 \mathrm{rstu}$ & $3.000 \mathrm{mnopq}$ & $5.000 \mathrm{ijkl}$ & 8.000 bcdef & $9.000 \mathrm{abc}$ & 5.200 & \\
\hline & $10.00 \mathrm{ppm}$ & 3.333 lmnop & $5.000 \mathrm{ijkl}$ & 6.667 efghi & 8.333 abcde & $10.000 \mathrm{a}$ & 6.666 & \\
\hline \multirow{5}{*}{ TITAN $48 \%$} & 0.00 & $0.000 \mathrm{u}$ & $0.000 \mathrm{u}$ & $0.000 \mathrm{u}$ & $0.000 \mathrm{u}$ & 0.000 u qrstu & 0.000 & \multirow{5}{*}{4.466} \\
\hline & $1.00 \mathrm{ppm}$ & $0.000 \mathrm{u}$ & $0.667 \mathrm{stu}$ & 3.667 klmno & 6.333 fghi & $10.000 \mathrm{a}$ & 4.133 & \\
\hline & $2.50 \mathrm{ppm}$ & $0.333 \mathrm{tu}$ & 2.000 opqrst & 3.667 klmno & 8.000 bcdef & $10.000 \mathrm{a}$ & 4.800 & \\
\hline & $5.00 \mathrm{ppm}$ & $0.667 \mathrm{stu}$ & 3.667 klmno & 5.667 ghij & $8.667 \mathrm{abcd}$ & $10.000 \mathrm{a}$ & 5.733 & \\
\hline & $10.00 \mathrm{ppm}$ & $1.333 \mathrm{qrstu}$ & 7.000 defgh & 8.000 bcdef & $10.000 \mathrm{a}$ & $10.000 \mathrm{a}$ & 7.266 & \\
\hline \multirow{5}{*}{ Goldti 5Ec } & 0.00 & $0.000 \mathrm{u}$ & $0.000 \mathrm{u}$ & $0.000 \mathrm{u}$ & $0.000 \mathrm{u}$ & $0.000 \mathrm{u}$ & 0.000 & \multirow{5}{*}{5.613} \\
\hline & $1.00 \mathrm{ppm}$ & $0.667 \mathrm{stu}$ & $0.667 \mathrm{stu}$ & 2.333 nopqrs & 5.667 ghij & 6.667 efghi & 3.200 & \\
\hline & $2.50 \mathrm{ppm}$ & $4.000 \mathrm{jklm}$ & 5.667 ghij & 5.667 ghij & 8.333 abcde & 8.333 abcde & 6.400 & \\
\hline & $5.00 \mathrm{ppm}$ & 6.667 efghi & 8.000 bcdef & $9.000 \mathrm{abc}$ & $9.667 \mathrm{ab}$ & $10.000 \mathrm{a}$ & 8.666 & \\
\hline & $10.00 \mathrm{ppm}$ & 8.000 bcdef & $9.333 \mathrm{ab}$ & $9.667 \mathrm{ab}$ & $10.000 \mathrm{a}$ & $10.000 \mathrm{a}$ & 9.400 & \\
\hline $\mathrm{C}$ & & 1.755 & 3.428 & 4.422 & 6.222 & 7.377 & & 4.640 \\
\hline \multirow{3}{*}{$\mathrm{AC}$} & Delta Ride & 0.933 & 2.750 & 3.600 & 5.200 & 6.599 & \multirow{3}{*}{ B } & 4.612 \\
\hline & TITAN $48 \%$ & 0.466 & 2.666 & 4.266 & 6.666 & 8.266 & & 4.612 \\
\hline & Goldti 5 & 3.866 & 4.733 & 5.400 & 6.800 & 7.266 & & 4.612 \\
\hline \multirow{5}{*}{$\mathrm{BC}$} & 0.00 & 0.000 & 0.000 & 0.000 & 0.000 & 0.000 & 0.000 & 4.612 \\
\hline & $1.00 \mathrm{ppm}$ & 0.222 & 0.555 & 2.555 & 5.222 & 7.333 & 3.177 & 4.612 \\
\hline & $2.50 \mathrm{ppm}$ & 1.555 & 3.444 & 4.555 & 7.333 & 8.555 & 5.088 & 4.612 \\
\hline & $5.00 \mathrm{ppm}$ & 2.778 & 4.889 & 6.555 & 8.778 & 9.666 & 6.533 & 4.612 \\
\hline & $10.00 \mathrm{ppm}$ & 4.222 & 7.111 & 8.111 & 9.444 & 10.000 & 7.777 & 4.612 \\
\hline
\end{tabular}

Propit line in Figure 3 indicated to the toxicity of the pesticide used on A. mellifera ligustica

\section{Fat bodies}

Generally, the first change in the perivisceral fat cells was the development of small vacuoles in the cytoplasm. This occurred in all races of honey bee workers in the control experiment (Fig. 10). The fat cells showed a series of changes in the cytoplasm when exposed to the recommended dose. The granulated cytoplasm developed a few droplets while the nucleus remained unchanged. In a few cells the granulated cytoplasm accumulated around the central nucleus. Increasing the dose to $10 \mathrm{ppm}$ caused more alterations in cell features. The round cells developed scattered inclusions and their nucleus disintegrated. The fat bodies showed a few changes in their features with droplets forming throughout the cytoplasm. The cytoplasm became slightly more granular than normal. 


$$
-5052-
$$

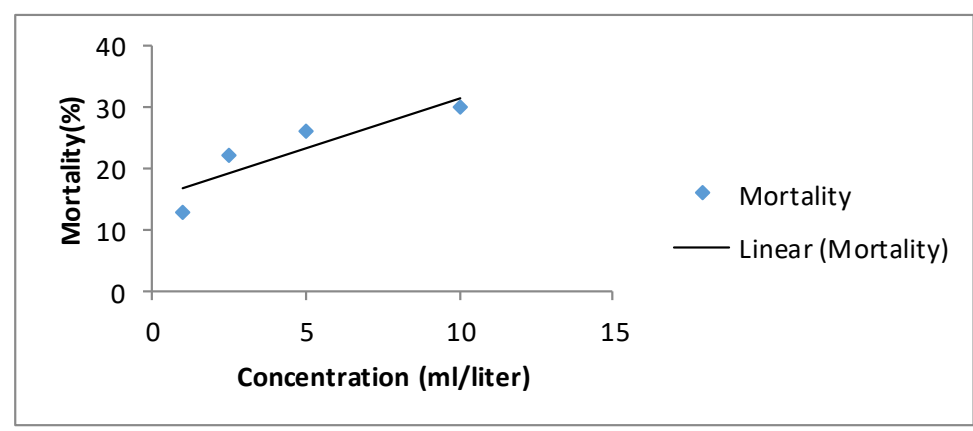

Figure 1. Effect of pesticides on A. mellifera native LC50 1.45 of Delta Ride feeding

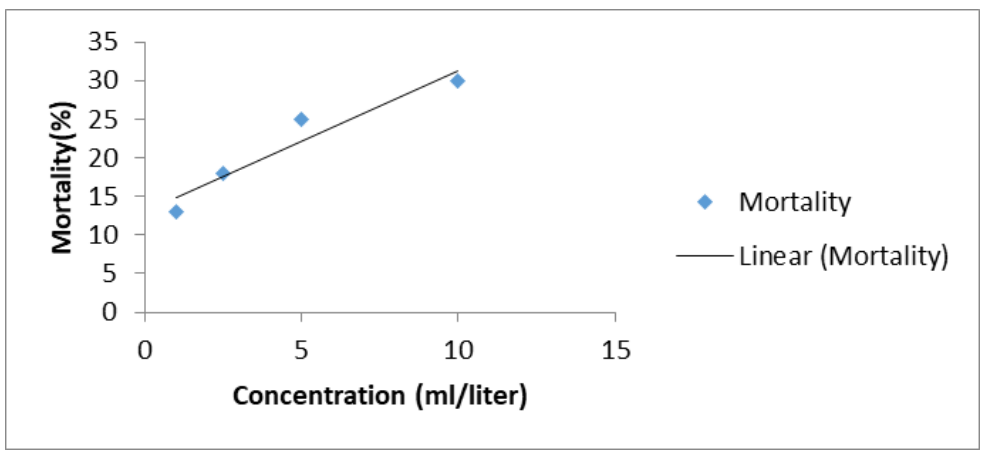

Figure 2. Effect of pesticides on A. mellifera native LC50 1.70 of Titan $48 \%$ feeding

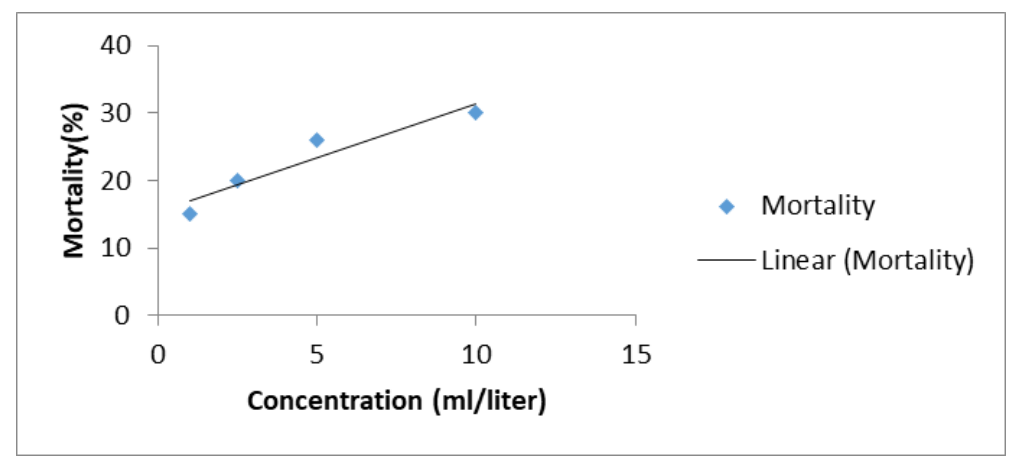

Figure 3. Effect of pesticides on A. mellifera native LC50 1.37 of Goldti 5 feeding

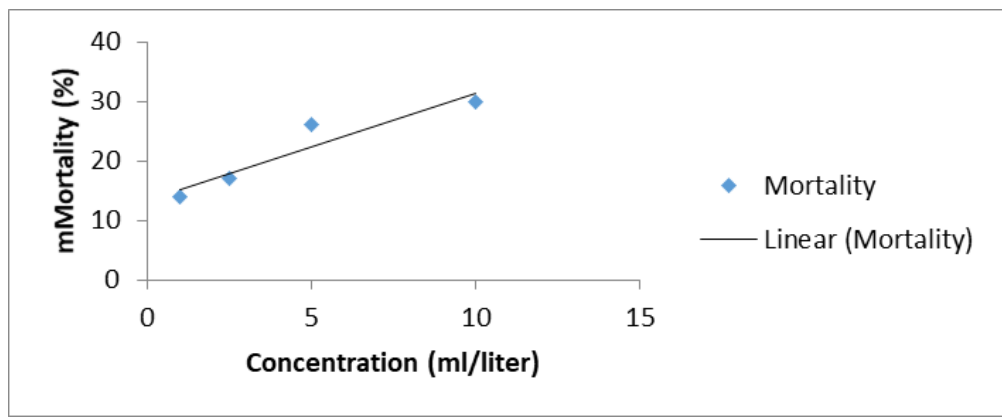

Figure 4. Effect of pesticides on A. mellifera carnica LC50 1.63 of Delta Ride feeding 


$$
\text { - } 5053 \text { - }
$$

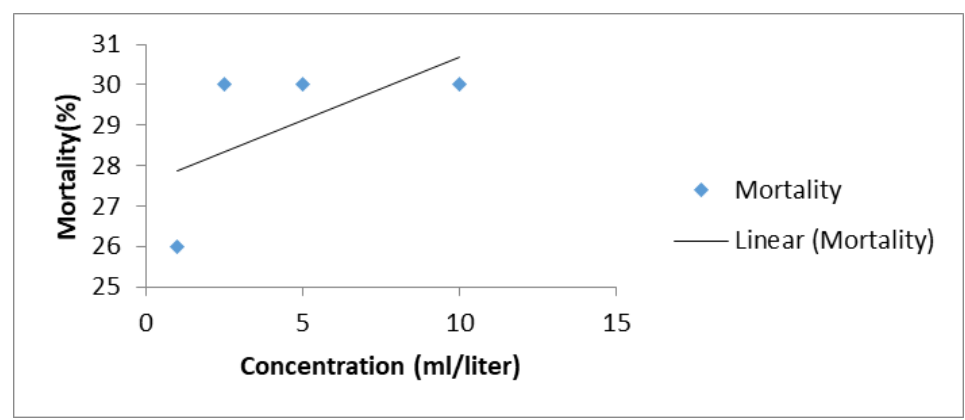

Figure 5. Effect of pesticides on A. mellifera carnica LC50 0.483 of Titan $48 \%$ feeding

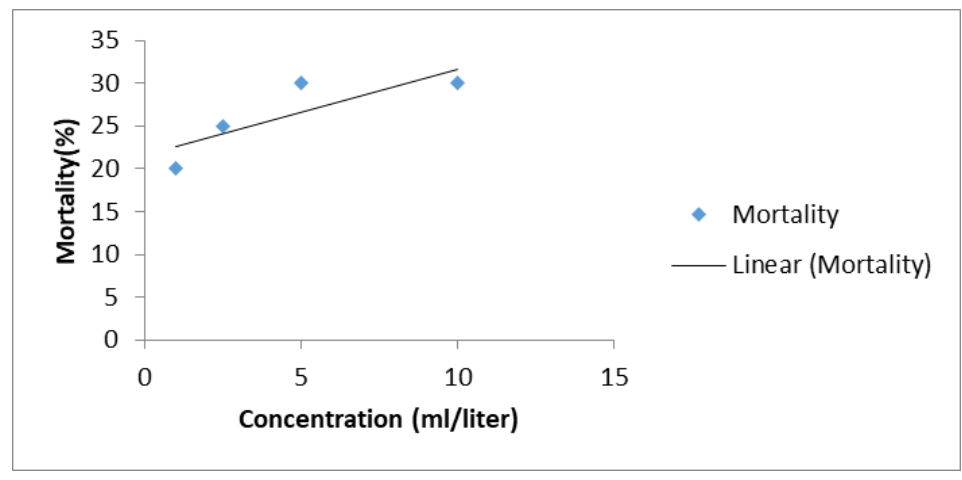

Figure 6. Effect of pesticides on A. mellifera carnica LC50 1.75 of Goldti 5 feeding

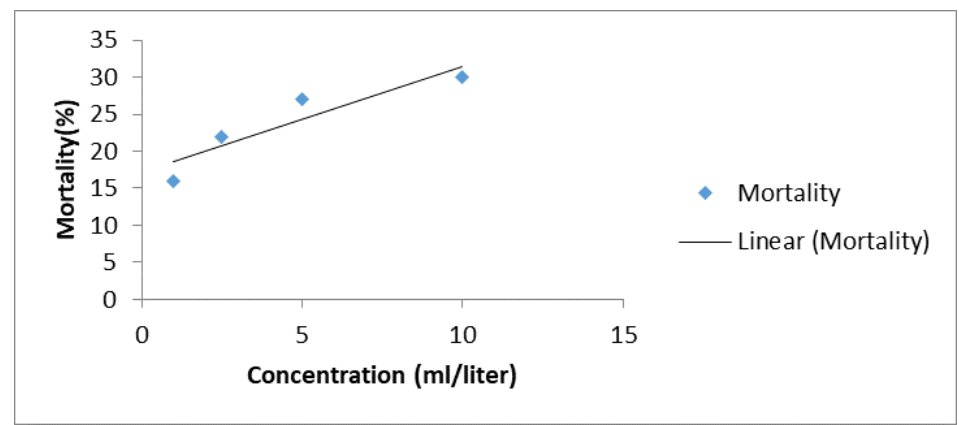

Figure 7. Effect of pesticides on A. mellifera ligustica LC50 1.17 of Delta Ride feeding

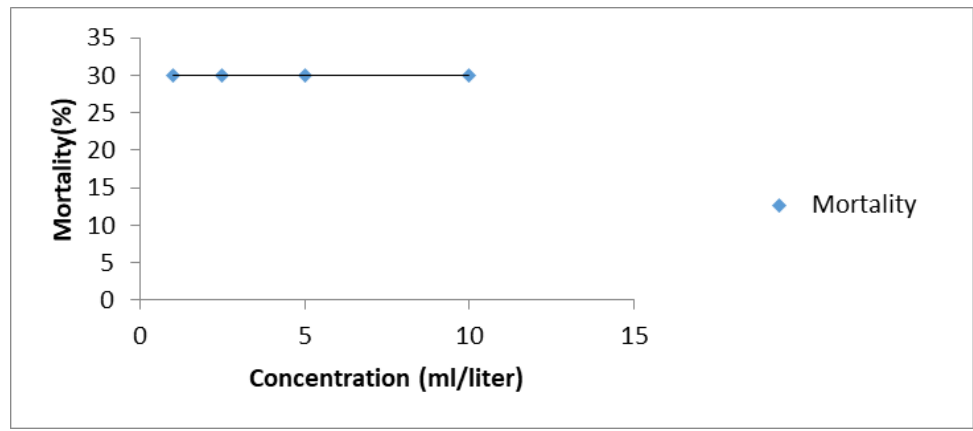

Figure 8. Effect of pesticides on A. mellifera ligustica LC50 0.50 of Titan $48 \%$ feeding 


$$
-5054 \text { - }
$$

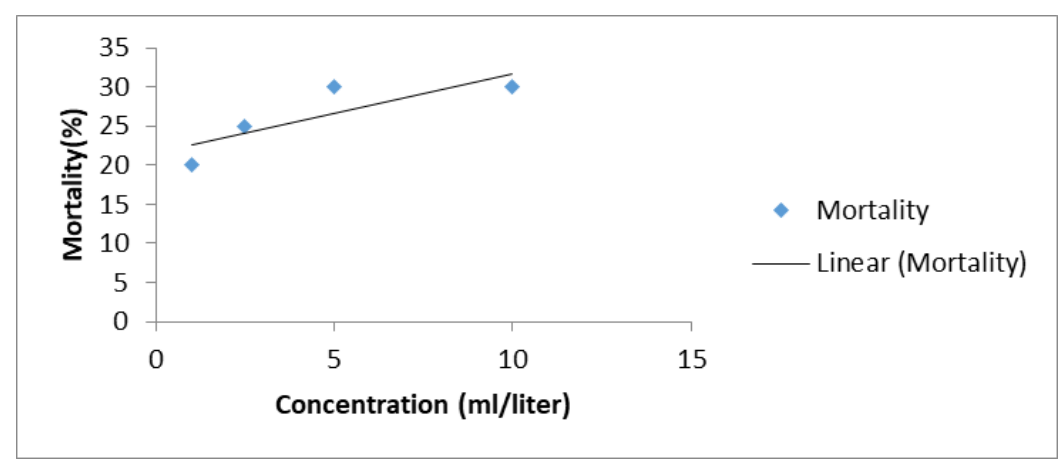

Figure 9. Effect of pesticides on A. mellifera ligustica LC50 0.437 of Goldti 5 feeding

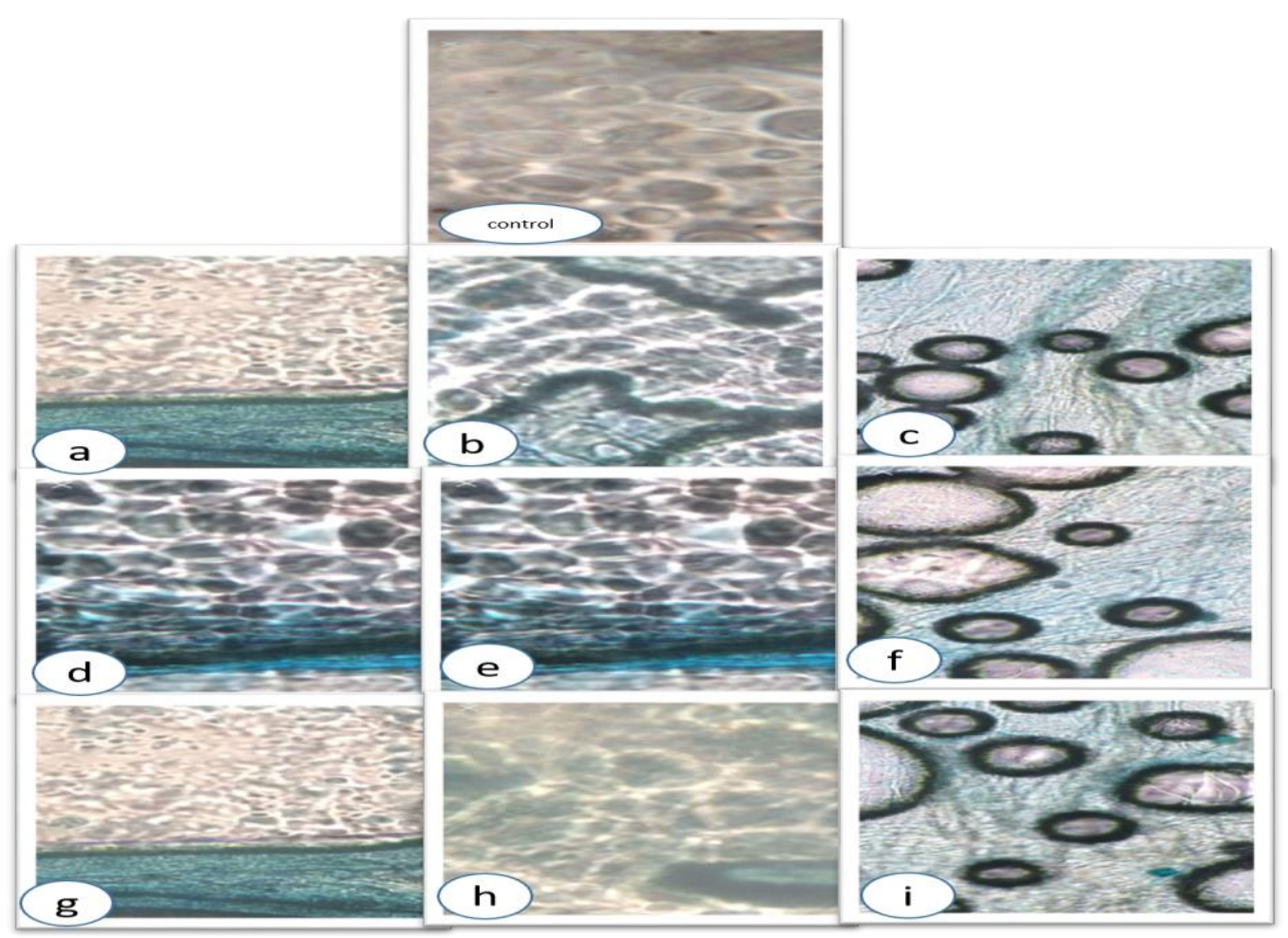

Figure 10. Effect of pesticides on fat bodies of three races of honeybee workers: A. mellifera carnica, A. mellifera ligustica, A. mellifera Native

The results are in agreement with Pham-Delègue et al. (2002), who found that the effect of insecticides on the direction sense of bees (reproductive ability), their communicative ability (bee dance language), and their foraging activity (olfactory learning performance) are affected by the LD50 of insecticides, and also agrees with EPPO (1993) and Thompson (2003) who found that the insecticides affect the bee larvae, division of labor, foraging, as well as the development of bee colonies while exposed to a lower lethal dose. The results are also in agreement with Bohnenblust et al. (2016), who found that nearly $80 \%$ of all pesticides applied to row crops are herbicides, and these applications pose potentially significant ecotoxicological risks to non-target plants and associated pollinators. The results similarly agree with Krupke et al. (2012), who found that bees are exposed to these compounds and several other agricultural 
pesticides in several ways throughout the foraging period. During spring, extremely high levels of clothianidin and thiamethoxam were found in planter exhaust material produced during the planting of treated maize seeds.

\section{Conclusion}

Laboratory tests of oral ingestion application of different pesticides to susceptible honeybee foragers revealed that the most effective herbicide affecting Apis mellifera carnica was TITAN $48 \%$, and that foragers are susceptible to toxicities of various pesticides (insecticides, herbicides) including pesticides not normally thought to affect them, generally having negative effects on fat bodes.

Acknowledgements. This manuscript is part of the $\mathrm{PhD}$ Thesis of the first author.

\section{REFERENCES}

[1] Abbott, K. A. (1925): A method of computing the effectiveness of an insecticide. - J. Econ. Entomol. 18: 265-267.

[2] Ayoub, Z. N. (2011): Workers ontogeny in queen less or brood less colonies of honey bee (Apis mellifera L.). - Ph. D. Thesis. Faculty of Biology and Earth Science, Jagiellonian University, Poland.

[3] Bohnenblust, E. W., Vaudo, A. D., Egan, J. F., Mortensen, D. A., Tooker, J. F. (2016): Effects of the herbicide dicamba on nontarget plants and pollinator visitation. Environmental Toxicology and Chemistry 35: 144-151.

[4] Buczek, K. (2009): Honey bee colony collapse disorder (CCD) [Zespo masowego giniecia pszczoy miodnej (CCD)]. - Annales Universitatis Mariae Curie Skodowska Sectio DD, Medicina Veterinaria 64: 1-6.

[5] Cameron, S. A., Lozier, J. D., Strange, J. P., Koch, J. B., Cordes, N. (2011): Patterns of widespread decline in North American bumble bees. - Proceedings of the National Academy of Science USA 108: 662-667.

[6] Chapman, R. F. (1978): The Insect Structure and Function. - Engl. Univ. Press. Ltd., London, England.

[7] Cook, B. T., Meola, S. (1983): Heart structure and beat in the stable fly, stomoxys calcitrans L. - Physiol. Entomol. 8: 139-149.

[8] Cox-Foster, D. L., Conlan, S., Holmes, E. C., Palacios, G., Evans, J. D. (2007): A metagenomic survey of microbes in honey bee colony collapse disorder. - Science 318: 283-287.

[9] Croft, B. (1990): Arthropod Biological Control Agents and Pesticides. - Wiley, New York.

[10] Dalaly, B. K., Awad, H. I., Al-jboory, I. J. (2012): Pesticides Used and Registered in Agriculture and Public Health in Iraq. - Ministry of Agriculture, Republic of Iraq.

[11] De Jong, F. M. W., de Snoo, G., van de Zande, J. C. (2008): Estimated nationwide effects of pesticide spray drift on terrestrial habitats in the Netherlands. - J Environ Manag 86: 721-730.

[12] EPPO (1993): Decision making scheme for the environmental risk assessment of plant protection products. Chapter 10. Honey bees. - Bull. OEPP/EPPO Bull. 23: 151-165.

[13] Johnson, R. M., Ellis, M. D., Mullin, C. A., Frazier, M. (2010): Pesticides and honey bee toxicity - USA. - Apidologie 41(3): 312-331. 
[14] Herbert, L. T., Vázquez, D. E., Andréas, A., Farina, W. M. (2014): Effects of fieldrealistic doses of glyphosate on honey bee appetitive behaviour. - J. Exp. Biol. 217: 3457-3464.

[15] Krupke, C. H., Hunt G. J., Eitzer B. D., Andino G., Given K. (2012): Multiple routes of pesticide exposure for honey bees living near agricultural fields. - PloS one 7: e29268.

[16] Maini S, Medrzycki P., Porrini C. (2010): The puzzle of honey bee losses: a brief review. - Bulletin of Insectology 63: 153-160.

[17] Mahmoud, T. T. (1991): Taxonomical and physiological studies on syrphid flies in Iraq. Dirasat. 188: 116-125.

[18] Mahmoud, T. T. (1992): Comparative anatomical and histological study of the heart of four syrphid. - Pakistan Journal of Scientific and Industrial Research 35(5): 182-184.

[19] Martel, A.-C., Zeggane, S., Aurieres, C., Drajnudel, P., Faucon, J.-P., Aubert, M. (2007): Acaricide residues in honey and wax after treatment of honey bee colonies with Apivar. $\mathrm{R}$ or AsuntolR50. - Apidologie. 38: 534-44.

[20] Maus, C., Curé, G., Schmuck, R. (2003): Safety of imidacloprid seed dressings to honey bees: a comprehensive overview and compilation of the current state of knowledge. Bull. Insectol. 56(1): 51-57.

[21] OECD (1998a). Guideline 213: Honey Bees. Acute Oral Toxicity Test. - OECD Guidelines for the Testing of Chemicals. Dir 2001/59/EC (O.J. L225 2001).

[22] Oerke, E. C., Dehne, H. W. (2004): Safeguarding production-losses in major crops and the role of crop protection. - Crop Prot 23: 275-285.

[23] Olivera, V. T. P., Cruz-Landim, C. (2003): Morphology and function of insect fat body cells: A review. - Biociencias, Proto Algre 11(2): 195-205.

[24] Osborne, J. L. (2012): Ecology: Bumblebees and pesticides. - Nature 491: 43-45.

[25] Pham-Delègue, M.-H., A. Decourtye, L. Kaiser, and J. Devillers. (2002): Behavioural methods to assess the effects of pesticides on honey bees. - Apidologie 33: 425-432.

[26] Pantine, C. F. A. (1964): Notes on Microscopical Techniques for Zoologists. 6th Ed. Cambridge University Press, Cambridge.

[27] Roma, G. C., Bueno, O. C., Camargo-Mathias, M. I. (2010): Morpho-physiological analysis of the insect fat body: a review. - Micron 41: 395-401.

[28] Shamdin, Z. N.(2003): Effect of supplemental protein and vitamins on the development of specific tissues with special concern to their fine structure in relation to the activity of honey bee workers Apis mellifera L.(Hymenoptera: Apidae) M.Sc. - Thesis, College of Agriculture. Univ of Dohuk.

[29] Snodgrass, R. E., Erickson, E. H. (2003): The Anatomy of Honey Bee. - In: Graham, J. M. (ed.). The Hive and Honey Bee. Revised Ed. Dadant \& Sons. Hamilton, IL.

[30] Sol Balbuena, M., Tison L., Hahn, M.-L., Greggers U., Menzel R., Farina W. M. 2015. Effects of sub-lethal doses of glyphosate on honey bee navigation. - The Journal of Experimental Biology. DOI: 10.1242/jeb.117291.

[31] Thompson, H. M. (2003): Behavioural effects of pesticide in bees-their potential for use in risk 10 assessment. - Ecotoxicology 12: 317-330.

[32] Thompson, H. Ball, R. Brown, M., Bew, M. (2003): Varroa destructor resistance to pyrethroid treatments in the United Kingdom. - Bulletin of Insectology 56: 175-181.

[33] Thompson, H. M., Levine, S. L., Doering, J., Norman, S., Manson, P., Sutton, P. von Mérey, G. (2014): Evaluating exposure and potential effects on honey bee brood (Apis mellifera) development using glyphosate as an example. - Integr. Environ. Assess. Manag. 10: 463-470.

[34] Tornier, I.; Kling, A., Schur, A. (2003): Honey bee testing in Southern Europe: from the laboratory to the relevant crop in the field. - Bull. Insectol. 56(1): 185-187.

[35] Underwood, R. M., Van Engelsdorp, D. (2007): Colony collapse disorder: have we seen this before? - Bee Culture 135: 13-15.

[36] Ware, G. W., Whitacre, D.M. (2004): The Pesticide. 6th Ed. - Meister Publication, Willoughby, Ohio. 


$$
-5057 \text { - }
$$

[37] Zhu, W., Schmehl, D. R., Mullin, C. A., Frazier, J. L. (2014): Four common pesticides, their mixtures and a formulation solvent in the hive environment have high oral toxicity to honey bee larvae. - PLoS One 9(1): e77547.

[38] Zanini, D. A., Caetano, F. H. (2003): Ultra structure of the visceral fat body of the Wasp Michocyttarus Cerberus styx. (Hymenoptera: Vespidae). - Acta Microscopica 12(B): 593.

\section{ELECTRONIC APPENDICES}

\section{ANOVA tables}

1. Apis mellifera carnica-feeding

2. Apis mellifera ligustica-feeding

3. Apis mellifera Native-feeding 